\title{
Obesity and happiness: does gender matter?
}

\author{
Ehsan Latif ${ }^{*}$ \\ Department of Economics, Thompson Rivers University, Canada
}

Received: 3 August 2013

Revised: 15 January 2014

Accepted: 22 January 2014

\begin{abstract}
This study used longitudinal Canadian data from the National Population Health Survey (NPHS), covering a period of 1994-2006, to examine the impact of obesity on happiness. In order to control for unobserved individual-specific fixed effects, this study utilized the fixed effects method. The study found that obesity significantly reduces happiness for females, while it has an insignificant impact on happiness for males. The study further found that the negative impact of obesity on happiness is concentrated among females in prime working age group and also among females with a higher level of education.
\end{abstract}

Keywords: obesity, BMI, happiness, Canada

JEL Classification Codes: I10, I31

\section{Introduction}

A recent OECD statistics suggest that 2 out of 3 men are overweight and that 1 in 4 people are obese in Canada. The same report projected that overweight and obesity rates are expected to grow by $8 \%$ during 2010-2010 (OECD, 2012). Overweight and obesity increase risk of a number of chronic conditions, such as cancer, stroke, diabetes, asthma, hypertension, and arthritis (World Health Organization, 2011). A number of studies have examined the labormarket-related cost associated with obesity, such as impact on employment prospect and wages (Cawley J., 2004; Averett \& Korenman, 1996). A neglected area of research is the impact of obesity on individual happiness. So far, only a few studies in the Economics of Happiness have delved into this issue. A study by Stutzer (2007), using cross-sectional data from Swiss Health Survey 2002, revealed that obesity decreased the subjective well-being of individuals who reported limited self-control. Using cross-sectional data from the British Household Panel Surveys (BHPS) and from the German Socioeconomic Panel Surveys (GSOEP), Oswald \& Powdthavee (2007) found that BMI is negatively correlated with life satisfaction. In a recent study, Katsaiti ( 2012) used panel data from the German SocioEconomic Panel (GSOEP), UK British Household Panel Survey (BHPS), and Australia

\footnotetext{
*E-mail: elatif@tru.ca.

Citation: Latif, E. (2014) Obesity and happiness: does gender matter?, Economics and Business Letters, 3(1), 5967.
} 
Household, Income and Labour Dynamics in Australia (HILDA) and found that, in all three countries, obesity had a negative effect on the subjective well-being of individuals.

The present study contributes to the literature in the following ways. First, unlike other studies, this study conducted sub-group analyses based on gender, age, and education; second, to the best of the author's knowledge, this is the first Canadian study related to this issue; third, unlike other study that used panel data, this study used an individual fixed-effects approach to control for unobserved individual-specific fixed effects.

This paper presents the following structure: Section 2 deals with the data and methodology, Section 3 presents the results, and Section 4 concludes.

\section{Data}

This study applied Canadian panel data from the National Population Health Survey (NPHS), covering a period of 1994-2006. The NPHS collects information related to the health and socio-demographic profiles of the Canadian population. The NPHS has three components: households, health institutions, and the North; this study used data from the household component. ${ }^{1}$ Starting in 1994/1995, the survey for the household component is conducted every two years. This study restricts the sample to individuals ages 16 and 64, yielding 28,952 person-wave observations.

The dependent variable of this study is happiness, which is measured using the following ordered responses: 1) so unhappy in life, 2) very unhappy, 3) somewhat unhappy, 4) somewhat happy, and 5) happy in life.

The independent variable, obesity, is a dichotomous variable indicating whether or not a person is obese. An individual is considered obese when his or her Body Mass Index (BMI), a measurement obtained by dividing a person's weight in kilograms by the square of the person's height in meters, equals or exceeds 30 (Health Canada, 2003). The model includes a number of socio-demographic determinants of happiness, such as age, marital status, education, health, home ownership, location, household income, and unemployment status. Age is a continuous variable while the age squared is included in the model to capture the non-linear impact of age on happiness. Marital status is a dummy variable with three categories: single, married, and widow/separated/divorced. The base category is single. Education is a four-category dummy variable with categories of less than secondary, secondary graduate, some post-secondary, and college/university education. The base category is less than secondary. Health status is another dummy variable with five categories: poor, fair, good, very good, and excellent health. The base category is poor health. The dummy variable of home ownership measures whether or not an individual owns a home. The independent variable of location measures whether or not an individual lives in an urban area. The variable of household income is a continuous variable that measures the total income of all household members. The dummy variable of unemployment indicates whether or not the individual is unemployed.

\section{Empirical methods}

This study used the following empirical model:

$$
H_{i t}=\beta_{0}+X_{i t} \beta_{x}+\beta_{u} O_{i t}+\mu_{i}+\varepsilon_{i t}
$$

\footnotetext{
${ }^{1}$ The North component refers to the survey carried out in Yukon and Northwest Territories situated in the Northern part of Canada.
} 
where $\mathrm{H}_{\mathrm{ijt}}$ represents outcome (happiness score) for individual $\mathrm{i}$ in year t. $\mathrm{X}_{\mathrm{it}}$ represents a vector of observed individual-specific characteristics such as age, squared age, marital status, education, health, location, home ownership, household income, and unemployment status. ${ }^{2}$ $\mathrm{O}_{\text {it }}$ indicates the obesity status of individual $\mathrm{i}$ in year t. $\mu_{\mathrm{i}}$ represents individual-specific unobserved fixed effect, while $\varepsilon_{i t}$ is the error term.

Application of the Ordinary Least Square (OLS) method is a simple way of estimating equation 1. However, the pooled OLS method does not control for individual-specific unobserved fixed effects, and consequently, the estimates using the pooled OLS will not be consistent. To solve this problem, following Oswald \& Powdthavee (2008), this study will utilize an individual-specific fixed effect method. This method factors out unobserved individual-specific fixed effects from the happiness equation. ${ }^{3}$ There may also be problem of dual causality as only age and gender are exogenous variables by nature. To test whether there is evidence of endogeneity, the study will run the Hausman test. If the Hausman test suggests presence of endogeneity, the study will utilize panel fixed effect instrumental variable method.

To check the robustness of the results, the study will re-estimate all models using BMI as an independent variable instead of Obesity.

\section{Results}

Table 1 shows the descriptive statistics. Following Baltagi (2005), the study used an F test to examine the presence of unobserved individual specific heterogeneity. The $\mathrm{F}$ tests confirmed the presence of unobserved individual specific heterogeneity and thus fixed effects regression were chosen over the pooled OLS method. To test whether there is a problem of dual causality, the study utilized the Hausman test. The Hausman test suggests that endogeneity is not a problem for the samples used in this study. So the study decided to use fixed effects method to examine the relationship between obesity/BMI and happiness. The results of the fixed-effect regressions are provided in Table 2. The second column of Table 2 shows the results for the overall sample. The results suggest that obesity has a negative but insignificant impact on happiness. Other important results include the following: being married has a significant positive impact while being widowed/separated/divorced has a significant negative effect on happiness, health has a significant positive impact on happiness, household income positively impacts happiness, while unemployment significantly reduces happiness. The third column shows the results of the male sample. The results in this sample suggest that, like the results of the overall sample, obesity has a positive but insignificant impact on happiness. Other results of the male sample are almost identical to the findings from the overall sample with the exceptions that household income and unemployment are not significant. The third column of Table 2 provides the results for the female sample. The results suggest that obesity significantly reduces happiness. Other results of the female sample are similar to the findings from the overall sample.

Thus, the results suggest that obesity has a significant negative impact on the happiness of females while it has insignificant effects on males' happiness. To further examine this issue, the study conducted sub-group analyses based on age and gender. The results, shown in Table 3, suggest that obesity has a significant negative impact on happiness for females aged between 25 and 54. In all other age categories, obesity has an insignificant

\footnotetext{
${ }^{2}$ In this study, unemployed is defined as an individual who has no job, but who is willing to work and is looking for job.

${ }^{3}$ The fixed effect method is not effective in the presence of unobserved time variant factors. In such cases, the instrumental variable method needs to be applied. However, the NPHS data set does not provide valid instruments, and consequently this study could not use the instrumental variable method.
} 
impact on happiness for both male and female samples. The results further suggest that, among the education categories, obesity has a significant negative effect on happiness only for females who have some post-secondary education.

To test robustness of these results, the study utilized fixed effects regressions with BMI as an independent variable. The results, shown in Table 4, suggest that BMI has a positive but insignificant impact on happiness for males while BMI has significant negative impact happiness for females. Thus the results suggest that 1unit increase in BMI will reduce happiness for females by .003 units. The results of the sub group analyses based on age and education are shown in Table 5. These results are qualitatively almost similar to the findings from the models using Obesity as an independent variable.

Table 1. Descriptive Statistics

\begin{tabular}{llll}
\hline \hline Variable & Overall & Male & Female \\
& Sample & Sample & Sample \\
\hline \hline Obese & .171 & .18 & .16 \\
Age & $(.003)$ & $(.004)$ & $(.004)$ \\
Single & 45.24 & 44.01 & 46.70 \\
& $(.101)$ & $(.145)$ & $(.136)$ \\
Married & .16 & .19 & .13 \\
& $(.003)$ & $(.005)$ & $(.003)$ \\
Divorced/ Widow & .71 & .73 & .69 \\
Less Than Secondary Education & $(.003)$ & $(.005)$ & $(.005)$ \\
Secondary Graduate Education & .13 & .08 & .18 \\
College- University Education & $(.002)$ & $(.003)$ & $(.004)$ \\
& .15 & .15 & .16 \\
Some Post -Secondary Education & $(.003)$ & $(.004)$ & $(.003)$ \\
& .16 & .15 & .17 \\
Home Ownership & $(.003)$ & $(.004)$ & $(.004)$ \\
& .43 & .44 & .41 \\
Residing in Urban Area & $(.004)$ & $(.006)$ & $(.005)$ \\
Household Income & .26 & .26 & .26 \\
& $(.003)$ & $(.005)$ & $(.004)$ \\
\hline \hline
\end{tabular}

Source: National Population Health Survey (1994-2006) 
Table 2: Regression results: determinants of happiness

\begin{tabular}{|c|c|c|c|}
\hline Variable & $\begin{array}{l}\text { Overall } \\
\text { Sample }\end{array}$ & $\begin{array}{l}\text { Male } \\
\text { Sample }\end{array}$ & $\begin{array}{l}\text { Female } \\
\text { Sample }\end{array}$ \\
\hline Obesity & $\begin{array}{l}.015 \\
(.013)\end{array}$ & $\begin{array}{l}.009 \\
(.017)\end{array}$ & $\begin{array}{l}.042 * \\
(.019)\end{array}$ \\
\hline Age & $\begin{array}{l}.006 \\
(.013)\end{array}$ & $\begin{array}{l}.011 \\
(.016)\end{array}$ & $\begin{array}{l}-.0006 \\
(.018)\end{array}$ \\
\hline Squared Age & $\begin{array}{l}-.00003 \\
(.00002)\end{array}$ & $\begin{array}{l}-.00001 \\
(.00004)\end{array}$ & $\begin{array}{l}-.00005 \\
(.00004)\end{array}$ \\
\hline Married & $\begin{array}{l}.045^{*} \\
(.017)\end{array}$ & $\begin{array}{l}.039 * * * \\
(.023)\end{array}$ & $\begin{array}{l}.049 * * \\
(.025)\end{array}$ \\
\hline Widow/ Separated/Divorced & $\begin{array}{l}-.082 * \\
(.025)\end{array}$ & $\begin{array}{l}-.099 * \\
(.036)\end{array}$ & $\begin{array}{l}-.069 * * \\
(.034)\end{array}$ \\
\hline Secondary Grad. & $\begin{array}{l}.014 \\
(.045)\end{array}$ & $\begin{array}{l}.027 \\
(.065)\end{array}$ & $\begin{array}{l}.019 \\
(.062)\end{array}$ \\
\hline Some Post-Secondary Education & $\begin{array}{l}-.023 \\
(.043)\end{array}$ & $\begin{array}{l}.019 \\
(.063)\end{array}$ & $\begin{array}{l}-.053 \\
(.059)\end{array}$ \\
\hline College University Education & $\begin{array}{l}-.002 \\
(.043)\end{array}$ & $\begin{array}{l}.061 \\
(.063)\end{array}$ & $\begin{array}{l}-.050 \\
(.059)\end{array}$ \\
\hline Excellent Health & $\begin{array}{l}.130 * \\
(.015)\end{array}$ & $\begin{array}{l}.110^{*} \\
(.021)\end{array}$ & $\begin{array}{l}.149 * \\
(.021)\end{array}$ \\
\hline Very Good Health & $\begin{array}{l}.107 * \\
(.016)\end{array}$ & $\begin{array}{l}.083 * \\
(.023)\end{array}$ & $\begin{array}{l}.129 * \\
(.023)\end{array}$ \\
\hline Good Health & $\begin{array}{l}.072 * \\
(.018)\end{array}$ & $\begin{array}{l}.049 * * \\
(.026)\end{array}$ & $\begin{array}{l}.091 * \\
(.026)\end{array}$ \\
\hline Fair Health & $\begin{array}{l}-.035 \\
(.025)\end{array}$ & $\begin{array}{l}-.083 \\
(.064)\end{array}$ & $\begin{array}{l}.002 \\
(.033)\end{array}$ \\
\hline Having Own Home & $\begin{array}{l}-.002 \\
(.012)\end{array}$ & $\begin{array}{l}-.002 \\
(.016)\end{array}$ & $\begin{array}{l}-.001 \\
(.017)\end{array}$ \\
\hline Living in Urban Area & $\begin{array}{l}.005 \\
(.009)\end{array}$ & $\begin{array}{l}-.005 \\
(.012)\end{array}$ & $\begin{array}{l}.015 \\
(.014)\end{array}$ \\
\hline Household Income & $\begin{array}{l}.012 * \\
(.005)\end{array}$ & $\begin{array}{l}.008 \\
(.006)\end{array}$ & $\begin{array}{l}.016^{*} \\
(.007)\end{array}$ \\
\hline Unemployed & $\begin{array}{l}-.041 * \\
(.016)\end{array}$ & $\begin{array}{l}-.037 \\
(.022)\end{array}$ & $\begin{array}{l}-.046 * * \\
(.024)\end{array}$ \\
\hline Constant & $\begin{array}{l}4.30 * \\
(.672)\end{array}$ & $\begin{array}{l}4.03 * \\
(.832)\end{array}$ & $\begin{array}{l}4.76 * \\
(.953)\end{array}$ \\
\hline Province Control & Yes & Yes & Yes \\
\hline Year Control & Yes & Yes & Yes \\
\hline Overall R-Squared & .0492 & .0255 & .0281 \\
\hline Number of Observations & 28952 & 13762 & 15190 \\
\hline
\end{tabular}

Notes: Significance: $* 1 \%$, ** 5\%

Omitted Variables: Single for Marital Status; Less than Secondary for Education; poor health for health status. 
Table 3: Impact of Obesity on Happiness by age and education

\begin{tabular}{|c|c|c|}
\hline Categories & $\begin{array}{l}\text { Male } \\
\text { sample }\end{array}$ & $\begin{array}{l}\text { Female } \\
\text { sample }\end{array}$ \\
\hline Age: less than 25 & $\begin{array}{l}-.219 \\
(.168)\end{array}$ & $\begin{array}{l}-.112 \\
(.240)\end{array}$ \\
\hline Overall R-Squared & .0109 & .0059 \\
\hline Number of Observations & 517 & 480 \\
\hline Age: between 25 and 54 & $\begin{array}{l}.009 \\
(.015)\end{array}$ & $\begin{array}{l}-.040 * \\
(.016)\end{array}$ \\
\hline Overall R-Squared & .0255 & .0281 \\
\hline Number of Observations & 9800 & 9919 \\
\hline Age : more than 54 & $\begin{array}{l}.067 \\
(.042)\end{array}$ & $\begin{array}{l}.026 \\
(.030)\end{array}$ \\
\hline Overall R-Squared & .0072 & .0063 \\
\hline Number of Observations & 3445 & 4791 \\
\hline Education: less than secondary & $\begin{array}{l}.022 \\
(.039)\end{array}$ & $\begin{array}{l}.019 \\
(.038)\end{array}$ \\
\hline Overall R-Squared & .0062 & .0201 \\
\hline Number of Observations & 2408 & 2751 \\
\hline Education: secondary graduate & $\begin{array}{l}.068 \\
(.039)\end{array}$ & $\begin{array}{l}-.080 \\
(.046)\end{array}$ \\
\hline Overall R-Squared & .0028 & .0007 \\
\hline Number of Observations & 1934 & 2356 \\
\hline Education: some post -secondary & $\begin{array}{l}.013 \\
(.030)\end{array}$ & $\begin{array}{l}-.144^{*} \\
(.036)\end{array}$ \\
\hline Overall R-Squared & .0329 & .0028 \\
\hline Number of Observations & 3583 & 4077 \\
\hline Education: college/university & $\begin{array}{l}-.027 \\
(.025)\end{array}$ & $\begin{array}{l}.025 \\
(.025)\end{array}$ \\
\hline Overall R-Squared & .0326 & .0032 \\
\hline Number of Observations & 5837 & 6006 \\
\hline
\end{tabular}

Note: Significance: $* 1 \%, * * 5 \%$

Full regressions are not shown to save space. The models include following controls: age, age squared, married, widow/ divorced, secondary graduate, post-secondary, college- university, household income, urban location, own home, provinces, and year dummies. 
Table 4: Regression results: determinants of happiness

\begin{tabular}{|c|c|c|c|}
\hline Variable & $\begin{array}{l}\text { Overall } \\
\text { Sample }\end{array}$ & $\begin{array}{l}\text { Male } \\
\text { Sample }\end{array}$ & $\begin{array}{l}\text { Female } \\
\text { Sample }\end{array}$ \\
\hline$\overline{\mathrm{BMI}}$ & $\begin{array}{l}-.0008 \\
(.0014)\end{array}$ & $\begin{array}{l}.007 \\
(.005)\end{array}$ & $\begin{array}{l}-.003 * * \\
(.001)\end{array}$ \\
\hline Age & $\begin{array}{l}.005 \\
(.010)\end{array}$ & $\begin{array}{l}.009 \\
(.012)\end{array}$ & $\begin{array}{l}-.001 \\
(.016)\end{array}$ \\
\hline Squared Age & $\begin{array}{l}-.00002 \\
(.00002)\end{array}$ & $\begin{array}{l}.00003 \\
(.00003)\end{array}$ & $\begin{array}{l}-.00005 \\
(.00003)\end{array}$ \\
\hline Married & $\begin{array}{l}.042 * \\
(.015)\end{array}$ & $\begin{array}{l}.035^{* * *} \\
(.019)\end{array}$ & $\begin{array}{l}.047 * * \\
(.023)\end{array}$ \\
\hline Widow/ Separated/Divorced & $\begin{array}{l}-.084 * \\
(.019)\end{array}$ & $\begin{array}{l}-.103^{*} \\
(.026)\end{array}$ & $\begin{array}{l}-.070 * * \\
(.028)\end{array}$ \\
\hline Secondary Grad. & $\begin{array}{l}.016 \\
(.038)\end{array}$ & $\begin{array}{l}.033 \\
(.054)\end{array}$ & $\begin{array}{l}.018 \\
(.054)\end{array}$ \\
\hline Some Post-Secondary Education & $\begin{array}{l}-.023 \\
(.031)\end{array}$ & $\begin{array}{l}.020 \\
(.046)\end{array}$ & $\begin{array}{l}-.054 \\
(.043)\end{array}$ \\
\hline College University Education & $\begin{array}{l}-.002 \\
(.032)\end{array}$ & $\begin{array}{l}.062 \\
(.047)\end{array}$ & $\begin{array}{l}-.052 \\
(.044)\end{array}$ \\
\hline Excellent Health & $\begin{array}{l}.129 * \\
(.012)\end{array}$ & $\begin{array}{l}.109 * \\
(.018)\end{array}$ & $\begin{array}{l}.148^{*} \\
(.019)\end{array}$ \\
\hline Very Good Health & $\begin{array}{l}.106^{*} \\
(.013)\end{array}$ & $\begin{array}{l}.082 * \\
(.018)\end{array}$ & $\begin{array}{l}.127 * \\
(.018)\end{array}$ \\
\hline Good Health & $\begin{array}{l}.071 * \\
(.013)\end{array}$ & $\begin{array}{l}.047 * \\
(.019)\end{array}$ & $\begin{array}{l}.092 * \\
(.019)\end{array}$ \\
\hline Fair Health & $\begin{array}{l}-.032 * * \\
(.016)\end{array}$ & $\begin{array}{l}-.081 * \\
(.023)\end{array}$ & $\begin{array}{l}.007 \\
(.022)\end{array}$ \\
\hline Having Own Home & $\begin{array}{l}-.001 \\
(.010)\end{array}$ & $\begin{array}{l}-.001 \\
(.014)\end{array}$ & $\begin{array}{l}-.002 \\
(.014)\end{array}$ \\
\hline Living in Urban Area & $\begin{array}{l}.005 \\
(.009)\end{array}$ & $\begin{array}{l}-.006 \\
(.012)\end{array}$ & $\begin{array}{l}.014 \\
(.013)\end{array}$ \\
\hline Household Income & $\begin{array}{l}.019 * \\
(.005)\end{array}$ & $\begin{array}{l}.013 * * * \\
(.007)\end{array}$ & $\begin{array}{l}.025^{*} \\
(.007)\end{array}$ \\
\hline Unemployed & $\begin{array}{l}-.042 * \\
(.013)\end{array}$ & $\begin{array}{l}-.039 * * \\
(.018)\end{array}$ & $\begin{array}{l}-.046 * * \\
(.022)\end{array}$ \\
\hline Constant & $\begin{array}{l}4.21 * \\
(.406)\end{array}$ & $\begin{array}{l}3.90 * \\
(.491)\end{array}$ & $\begin{array}{l}4.57 * \\
(.689)\end{array}$ \\
\hline Province Control & Yes & Yes & Yes \\
\hline Year Control & Yes & Yes & Yes \\
\hline Overall R-Squared & .0497 & .0281 & .0260 \\
\hline Observations & 28952 & 13762 & 15190 \\
\hline
\end{tabular}

Notes: Significance: $* 1 \%, * * 5 \%, * * * 10 \%$

Omitted Variables: Single for Marital Status; Less than Secondary for Education; poor health for health status. 
Table 5: Impact of BMI on Happiness by age and education

\begin{tabular}{|c|c|c|}
\hline Categories & $\begin{array}{l}\text { Male } \\
\text { sample }\end{array}$ & $\begin{array}{l}\text { Female } \\
\text { sample }\end{array}$ \\
\hline Age: less than 25 & $\begin{array}{l}-.002 \\
(.021)\end{array}$ & $\begin{array}{l}.029 \\
(.022)\end{array}$ \\
\hline Overall R- Squared & .0102 & .0043 \\
\hline Number of Observations & 517 & 480 \\
\hline Age: between 25 and 54 & $\begin{array}{l}.007 \\
(.015)\end{array}$ & $\begin{array}{l}-.029 * \\
(.001)\end{array}$ \\
\hline Overall R- Squared & .0211 & .0220 \\
\hline Number of Observations & 9800 & 9919 \\
\hline Age : more than 54 & $\begin{array}{l}.017 \\
.016)\end{array}$ & $\begin{array}{l}.006 \\
(.004)\end{array}$ \\
\hline Overall R- Squared & .0076 & .0070 \\
\hline Number of Observations & 3445 & 4791 \\
\hline Education: less than secondary & $\begin{array}{l}.007 \\
(.006)\end{array}$ & $\begin{array}{l}.005 \\
(.004)\end{array}$ \\
\hline Overall R- Squared & .0049 & .0203 \\
\hline Number of Observations & 2408 & 2751 \\
\hline Education: secondary graduate & $\begin{array}{l}.008 \\
(.005)\end{array}$ & $\begin{array}{l}-.009 \\
(.006)\end{array}$ \\
\hline Overall R- Squared & .0027 & .0006 \\
\hline Number of Observations & 1934 & 2356 \\
\hline Education: some post -secondary & $\begin{array}{l}.006 \\
(.004)\end{array}$ & $\begin{array}{l}-.011^{*} \\
(.004)\end{array}$ \\
\hline Overall R- Squared & .0286 & .0051 \\
\hline Number of Observations & 3583 & 4077 \\
\hline Education: college/university & $\begin{array}{l}.006 \\
(.004)\end{array}$ & $\begin{array}{l}.001 \\
(.003)\end{array}$ \\
\hline Overall R- Squared & .0317 & .0030 \\
\hline Number of Observations & 5837 & 6006 \\
\hline
\end{tabular}

Note: Significance: * $1 \%, * * 5 \%$

Full regressions are not shown to save space. The models include following controls: age, age squared, married, widow/ divorced, secondary graduate, post-secondary, college- university, household income, urban location, own home, provinces, and year dummies.

\section{Conclusion}

This study used longitudinal Canadian data from the National Population Health Survey (NPHS), covering a period of 1994-2006, to examine the impact of obesity on happiness. In order to control for unobserved individual-specific fixed effects, this study utilized the fixed effects method. The study found that obesity significantly reduces happiness for females, while it has an insignificant impact on happiness for males. The study further found that the negative impact of obesity on happiness is concentrated among females in prime working age group and also among females with a higher level of education. A robustness check using $\mathrm{BMI}$ as an independent variable also found similar results.

A limitation of the paper is that the BMI was calculated using self-reported rather than measured height and weight data. Studies suggest that subjects tend to overestimate height and underestimate weight and thus underestimate BMI (Stewart et al., 1987; Hill and Roberts, 1998). If data were available, then future studies may use the measured BMI variable and also may take into account the possible reverse causality issue. Further studies are needed to examine why obesity has a negative impact on some groups than on others. 
Acknowledgements. I like to thank the anonymous referee for valuable comments. I also like to thank Dr. Charlie Victorino, Analyst, Prairie Research Data Centre, for his help during my work on this project at the Research Data Centre.

\section{References}

Averett, S. and Korenman, S. (1996) The economic reality of the beauty myth, Journal of Human Resources, 31(2), 304-330.

Baltagi, B. (2005) Econometric analysis of panel data, third edition, John Wiley \& Sons Ltd., England.

Cawley, J. (2004) The impact of obesity on wages, Journal of Human Resources, 39(2), 451474.

Greve, J. (2008) Obesity and labor market outcomes in Denmark, Economics and Human Biology, 6(3), 350-362.

Health Canada (2003) Canadian guidelines for body weight classification in adults, Ottawa: Health Canada.

Hill, A. and Robert, J. (1998) Body mass index: a comparison between self-reported and measured height and weight, Journal of Public Health Medicine, 20, 206-210.

Katsaiti, M.S. (2012) Obesity and happiness, Applied Economics, 44(31), 4101-4114.

OECD (2012) Obesity and the Economics of Prevention: Fit not Fat, [www.oecd.org/health/fitnotfat]

Oswald, A.J. and Powdthavee, N. (2008) Does happiness adapt? A longitudinal study of disability with implications for economists and judges, Journal of Public Economics, 92(5-6), 1061-1077.

Oswald, A. and Powdthavee, N. (2007) Obesity, unhappiness, and the challenge of affluence: theory and evidence, Economic Journal, 117, 441- 459.

Stewart, A.W., Jackson, R.T., Ford, M.A. and Beaglehole, R. (1987) Underestimation of relative weight by use of self-reported height and weight, American Journal of Epidemiology, 125(1), 122-126.

Stutzer, A. (2007) Limited self-control, obesity and the loss of happiness, IZA Discussion Papers 2925, Institute for the Study of Labor IZA.

World Health Organization (2011) Global status report on non-communicable diseases 2010, Geneva, Switzerland: World Health Organization. 